\title{
Kevytmuokkaus ja suorakylvö kevyillä maalajeilla
}

\author{
Timo Lötjönen $^{1)}$, Essi Saarinen ${ }^{1)}$ ja Timo Keränen ${ }^{1)}$ \\ ${ }^{1)}$ Maa- ja elintarviketalouden tutkimuskeskus, Tutkimusasemantie 15, 92400 Ruukki \\ timo.lotjonen@mtt.fi
}

\section{Tiivistelmä}

Tutkimustieto uusien kevytmuokkausmenetelmien ja suorakylvön soveltuvuudesta keveille maalajeille on maassamme vähäistä. Tällaisia muokkaimia ovat esimerkiksi lautasmuokkaimet ja jäykkäpiikkiset kultivaattorit. Toisaalta viljelijöillä on suuri tarve leikata viljelyn kustannuksia, joten kyntöä edullisemmat menetelmät kiinnostavat. Lisäksi ympäristötukijärjestelmä kannustaa muokkauksen keventämiseen. Tämän tutkimuksen tavoitteena oli löytää edullisia ja hyvin toimivia viljakasvuston perustamisvaihtoehtoja hieta- ja turvemaille, eli verrata kynnön, kevytmuokkauksen ja suorakylvön sato- ja kustannusvaikutuksia toisiinsa.

Koejäseniksi valittiin kyntö syksyllä tai keväällä, lautasmuokkaus syksyllä tai keväällä, suorakylvö ja lisäksi yhdellä koepaikalla kultivointi syksyllä. Kolmivuotiset kokeet järjestettiin vuosina 2009 - 2011 Ruukissa turvemaalla, Haapajärvellä hieno/karkeahiedalla ja Kannuksessa karkeahiedalla. Kokeissa oli neljä toistoa, koeruudut pysyivät vuosittain samoilla paikoilla ja kasvina oli vuosittain ohra.

Kyntöä seurasi keväällä kaksi S-piikkiäestystä ja kylvö. Kevytmuokattuja lohkoja ei erikseen kylvömuokattu. Kaikki koejäsenet kylvettiin samalla suorakylvökoneella. Juolavehnä torjuttiin vuosittain glyfosaatilla joko syksyllä tai keväällä. Puinnin jälkeen oljet silputtiin maahan.

Kynnetyistä koejäsenistä saatiin tasaisen hyviä, 4000 - 6000 kg/ha (14 \%) ohrasatoja. Kevät- ja syyskyntö eivät eronneet toisistaan merkitsevästi, joten näillä mailla kynnön voi tehdä syksyllä tai keväällä. Aurattomista viljelytavoista parhaiten toimi keväällä tehty lautasmuokkaus, sen sato ei yleensä poikennut kynnetyistä. Syksyllä lautasmuokatun koejäsenen sato jäi usein kynnettyjä heikommaksi, keskimäärin noin 5 - $30 \%$ ja syksyllä kultivoidussa sato oli vielä heikompi, $30-50 \%$ kyntöä alempi. Turvemaalla suorakylvö toimi hyvin, keskimäärin saatiin noin $10 \%$ alempi sato kuin syyskynnöllä. Hietamaan koepaikoilla suorakylvettyjen ruutujen sato oli kahtena ensimmäisenä vuonna vähintään 30 \% alempi kuin kynnettyjen ruutujen, mutta parantui viimeisenä vuonna. Hehtolitrapainot eivät eronneet toisistaan merkitsevästi millään koepaikalla yhtenäkään koevuonna.

Syksyllä tehtyjen kevytmuokkausten ja suorakylvön heikompaa menestystä verrattuna keväällä tehtyyn lautasmuokkaukseen tai kyntöön selittänee maan nopeampi lämpiäminen ja kylänurmikan heikompi selviytyminen kevätmuokkauksen jäljiltä. Torjunta-aineet eivät tehonneet nurmikkaan ja jos mitään kevätmuokkausta ei tehty, nurmikka rajoitti selvästi viljan kasvua orasvaiheessa. Näillä maalajeilla sopiva viljakasvuston perustamistapa voisi olla keväällä tehty kevytmuokkaus yhdistettynä kiekkovannaskylvökoneeseen. Myös kyntö on edelleen hyvä vaihtoehto. Jos halutaan kevytmuokata jo syksyllä, kannattaisi keväälläkin ajaa vielä kertaalleen kevytmuokkarilla tai äkeellä ennen kylvöä. Nykyisillä viljan hinnoilla ja satotason ollessa noin 5 tonnia/ha, suorakylvön aiheuttama sadonalennus saisi olla korkeintaan 16 \%, jotta kynnöstä luopuminen kannattaisi. Kevytmuokkausmenetelmillä eron tulisi olla vielä pienempi.

Asiasanat: suorakylvö, kevytmuokkaus, lautasmuokkaus, kultivointi, kyntö, maanmuokkaus, hieta, eloperäiset maalajit 


\section{Johdanto}

Tutkimustieto uusien kevytmuokkausmenetelmien soveltuvuudesta keveille maalajeille on maassamme vähäistä. Suorakylvöä keveillä mailla on tutkittu jonkin verran (Isolahti ym. 2008), mutta tutkimustietoa esimerkiksi lautasmuokkainten ja uusien kultivaattoreiden toiminnasta ja satovaikutuksista ei ole. Toisaalta viljelijöillä on suuri tarve leikata viljelyn kustannuksia, joten kyntöä nopeammat ja edullisemmat muokkausmenetelmät kiinnostavat. Lisäksi ympäristötukijärjestelmä kannustaa muokkauksen keventämiseen.

Kyntö ja suorakylvö ovat käsitteinä hyvin vakiintuneita, kun taas kevytmuokkaus sisältää monia eri menetelmävaihtoehtoja. Olosuhteista riippuen maata voidaan muokata mm. järeällä Spiikkiäkeellä, lapiorullaäkeellä, kultivaattorilla, minisiipiauralla, lautasmuokkaimella tai lautasäkeellä (Pitkänen \& Mikkola 1998).

Tämän tutkimuksen tavoitteena oli löytää edullisia ja hyvin toimivia viljakasvuston perustamisvaihtoehtoja hieta- ja turvemaille, eli verrata kynnön, kevytmuokkauksen ja suorakylvön sato- ja kustannusvaikutuksia toisiinsa.

\section{Aineisto ja menetelmät}

Koejäseniksi valittiin syyskyntö, kevätkyntö, lautasmuokkaus syksyllä, lautasmuokkaus keväällä, suorakylvö ja lisäksi yhdellä koepaikalla kultivointi syksyllä (taulukko 1). Kokeet tehtiin ohralla, koska sen tiedetään herkimmin reagoivan maan liialliseen tiiveyteen ja kosteuteen sekä kasvitauteihin, jotka voivat olla ongelma muokkausta vähennettäessä (Känkänen ym. 2011). Kolmivuotiset kokeet järjestettiin vuosina 2009-2011 Ruukissa turvemaalla, Haapajärvellä hieno/karkeahiedalla ja Kannuksessa karkeahiedalla. Kokeet toteutettiin lohkoittain satunnaistettuna kokeena neljällä toistolla. Koeruudut (6 m x 30 m) pysyivät vuosittain samoilla paikoilla. Koko koe kylvettiin aina samalla ohralajikkeella ja ympäristötuen mukaisella lannoitemäärällä. Lajikkeina olivat Voitto, Vilde, Pilvi, Olavi ja Saana.

Taulukko 1. Koepaikkakunnilla käytetyt kevytmuokkaus- ja kylvökoneet.

\begin{tabular}{lccc}
\hline & Ruukki & Haapajärvi & Kannus \\
\hline Lautasmuokkaus & $\begin{array}{c}\text { VM 300/ } \\
\text { Väderstad Carrier }\end{array}$ & VM 300 & Amazone Catros 3001-T \\
\hline Kultivaattori & - & $\begin{array}{c}\text { Green Power } \\
\text { N 300 }\end{array}$ & - \\
\hline Kylvö, kaikki koejäsenet & VM 300 & VM 300 & Junkkari Maestro 3000 \\
\hline
\end{tabular}

Kyntöä seurasi keväällä kaksi S-piikkiäestystä ja kylvö. Lautasäestettyjä ja kultivoituja lohkoja ei erikseen kylvömuokattu ennen kylvöä. Kaikki koejäsenet kylvettiin samana päivänä samalla suorakylvökoneella, josta säädettiin ainoastaan kylvösyvyys siirryttäessä koejäseneltä toiselle. Kylvösyvyystavoitteena oli kynnetyillä ja kevytmuokatuilla ruuduilla $5 \mathrm{~cm}$ ja suorakylvössä 2-3 cm. Kylvöt tehtiin silloin, kun maa oli optimikuivuudessa suorakylvön kannalta, eli yleensä toukokuun lopulla. Muokattuja ruutuja varottiin kuivattamasta liikaa, mm. kylvömuokkaus tehtiin juuri ennen kylvöä. Juolavehnä torjuttiin vuosittain glyfosaatilla joko syksyllä tai keväällä. Kaksisirkkaiset rikkakasvit torjuttiin viljan orasvaiheessa MCPA- tai pienannosainevalmistein. Lakoa ja tauteja torjuttiin tarpeen mukaan. Puinnin jälkeen oljet silputtiin maahan.

Koeruuduista määritettiin vuosittain hehtaarisato, hehtolitrapaino, lakoisuus ja sadon valkuaispitoisuus. Tilastollisesti kutakin koepaikkaa ja koevuotta käsiteltiin erillisinä koepaikkojen välisen suuren vaihtelun takia. Kokeiden tilastollinen rakennemalli oli $\chi_{i j}=\mu+\alpha_{i}+\beta_{j}+\varepsilon_{i j}$. Aineiston normaalijakautuneisuuden tarkasteluun käytettiin SAS-ohjelmiston UNIVARIATE-proseduuria. Tulokset analysoitiin varianssianalyysillä käyttäen MIXED-proseduuria ja koekäsittelyjen parivertailu tehtiin TukeyKramerin testillä.

Tutkimuksen aikana kasvukaudet olivat tavanomaista lämpimämpiä vrk:n keskilämpötilalla ja kasvukauden lämpösummalla mitattuna (taulukko 2). Sademääriltään kasvukaudet olivat Ruukissa normaaleja tai tavanomaista kuivempia (alkukesät 2009 ja 2010). Muilla koepaikoilla sääolot olivat hyvin samansuuntaiset, päivittäisissä sademäärissä tosin saattoi olla suuriakin eroja. Karkeasta maala- 
jista ja vähäisestä alkukesän sadannasta johtuen kuivuus vaikutti satoon eniten Haapajärven koekentällä. Muilla paikoilla kuivuudesta ei ollut kovin merkittävää haittaa.

Taulukko 2. Kasvukauden sää Ruukissa vuosina 2009-2011 verrattuna pitkäaikaisiin keskiarvoihin (vertailujakso 1971-2000) (Lähde: Ilmatieteen laitos).

\begin{tabular}{llllllllll}
\hline & \multicolumn{4}{l}{ Sademäärä, mm } & \multicolumn{4}{c}{ Vrk:n keskilämpötila, ${ }^{\circ} \mathrm{C}$} \\
Kuukausi & 2009 & 2010 & 2011 & $\mathbf{1 9 7 1 - 2 0 0 0}$ & 2009 & 2010 & 2011 & $\mathbf{1 9 7 1 - 2 0 0 0}$ \\
\hline Toukokuu & 39.2 & 24.0 & 29.1 & $\mathbf{3 5 . 4}$ & 9.7 & 10.9 & 8.6 & $\mathbf{7 . 6}$ \\
Kesäkuu & 14.0 & 34.5 & 52.9 & $\mathbf{5 1 . 9}$ & 13.0 & 12.1 & 15.7 & $\mathbf{1 3 . 1}$ \\
Heinäkuu & 67.1 & 59.4 & 64.2 & $\mathbf{6 8 . 6}$ & 15.3 & 18.6 & 18.0 & $\mathbf{1 5 . 6}$ \\
Elokuu & 77.0 & 71.7 & 86.1 & $\mathbf{7 2 . 0}$ & 14.5 & 13.6 & 14.3 & $\mathbf{1 3 . 0}$ \\
Syyskuu & 57.5 & 64.9 & 81.4 & $\mathbf{4 8 . 7}$ & 10.6 & 8.9 & 10.9 & $\mathbf{7 . 9}$ \\
& & & & & & & & & \\
\multicolumn{1}{l}{ Tehoisa lämpötilasumma } & $1.5 .-30.9$. & & 1169 & 1212 & 1314 & $\mathbf{1 0 4 6}$ \\
\hline
\end{tabular}

Eri muokkausmenetelmäketjujen kustannukset laskettiin käyttäen TTS:n keräämiä urakointihintatilastoja (Palva 2011). Toinen vaihtoehto olisi ollut laskea jokaiselle koneelle kiinteät ja muuttuvat kustannukset, mutta tämä laskentatapa on hyvin herkkä vuotuiselle käyttömääräoletukselle. Kyntöketjussa oletettiin tarvittavan kaksi äestyskertaa ennen kylvöä. Kevytmuokkausketjuille kustannukset laskettiin kahdella tavalla: olettaen, että pelkkä yksi kevytmuokkauskerta riittää ja toisaalta niin, että lisäksi ennen kylvöä tarvitaan yksi äestys tai toinen kevytmuokkauskerta. Mikäli käytettävissä on laahavannaskylvökone, on todennäköistä, että muokkauskertoja tarvitaan kaksi kasvijätteiden riittävän multauksen saavuttamiseksi.

Kustannuslaskelmassa oletettiin, että kyntäen tapahtuvassa muokkauksessa glyfosaattia tarvitsee ruiskuttaa joka toinen vuosi juolavehnän ja muiden kestorikkakasvien torjumiseksi. Suorakylvössä glyfosaattiruiskutus oletettiin tehtäväksi joka vuosi ja kevytmuokkauksissa näiden kahden käyttötavan väliltä. Aiempi kevyillä mailla tehty suorakylvötutkimus osoitti glyfosaattiruiskutuksen jokavuotisen tarpeellisuuden suorakylvössä (Isolahti ym. 2008). Samassa tutkimuksessa vuosittain kyntämällä selvittiin kolmekin kasvukautta ilman glyfosaattiruiskutusta. Isolahden ym. (2008) ja nyt käsillä olevassa tutkimuksessa muokkaamattomuuden ei todettu lisänneen kasvitauteja selvästi, joten kustannuslaskelmassa muokkauksen keventämisen ei oletettu lisäävän kasvitautien torjuntatarvetta.

Kustannuslaskennan lisäksi kullekin muokkausketjulle laskettiin se sadon alenema, jolla ketjun tuomat kustannussäästöt vielä juuri kattavat viljan myynnistä saatavien tulojen pienenemisen kyntöketjuun verrattuna. Ts. sadon alenema ei saisi olla laskettua arvoa suurempi pitkällä aikavälillä. Viljan hinnaksi myytäessä oletettiin 150 e/tonni (alv. 0 \%). Koska jokaisen viljatonnin korjuu, kuivatus ja varastointi aiheuttaa kustannuksia, laskennassa viljan arvona on käytetty ns. pystyhintaa, eli myyntihinnasta on vähennetty puinti- ja kuivauskustannuksina 40 e/tonni (Palva 2011). Koska viljan hinta on vaihdellut viime vuosina paljon, raja-arvon herkkyyttä testattiin vielä viljan myyntihinnoilla 100 ja 200 e/tonni. Ympäristötuen vaikutusta ei tässä laskelmassa otettu huomioon.

\section{Tulokset ja tulosten tarkastelu}

Kolmen vuoden satotulosten mukaan kynnetyistä koejäsenistä saatiin 4000 - 6000 kg/ha (14 \%) ohrasatoja. Satovaihtelut eri menetelmien välillä olivat pienimpiä Ruukin turvemaalla ja suurimpia Haapajärven hiedalla (kuvat 1, 2 ja 3). Kevät- ja syyskyntö eivät eronneet toisistaan tilastollisesti merkitsevästi millään koepaikalla. Turvemaalla kevätkynnöstä saatiin pientä sadonlisää, kun hietamaalla tilanne oli usein päinvastainen. Syksyllä lautasmuokatun koejäsenen sato jäi usein kynnettyjä heikommaksi, keskimäärin noin 5 - 30 \%. Kevätlautasmuokkauksen sato oli hyvin lähellä kynnettyjen ruutujen satoa, vain kerran se oli turvemaalla tilastollisesti merkitsevästi kynnettyjä heikompi. Erityisen hyvin keväällä tehty lautasmuokkaus onnistui Kannuksen karkealla hiedalla (kuva 3). 


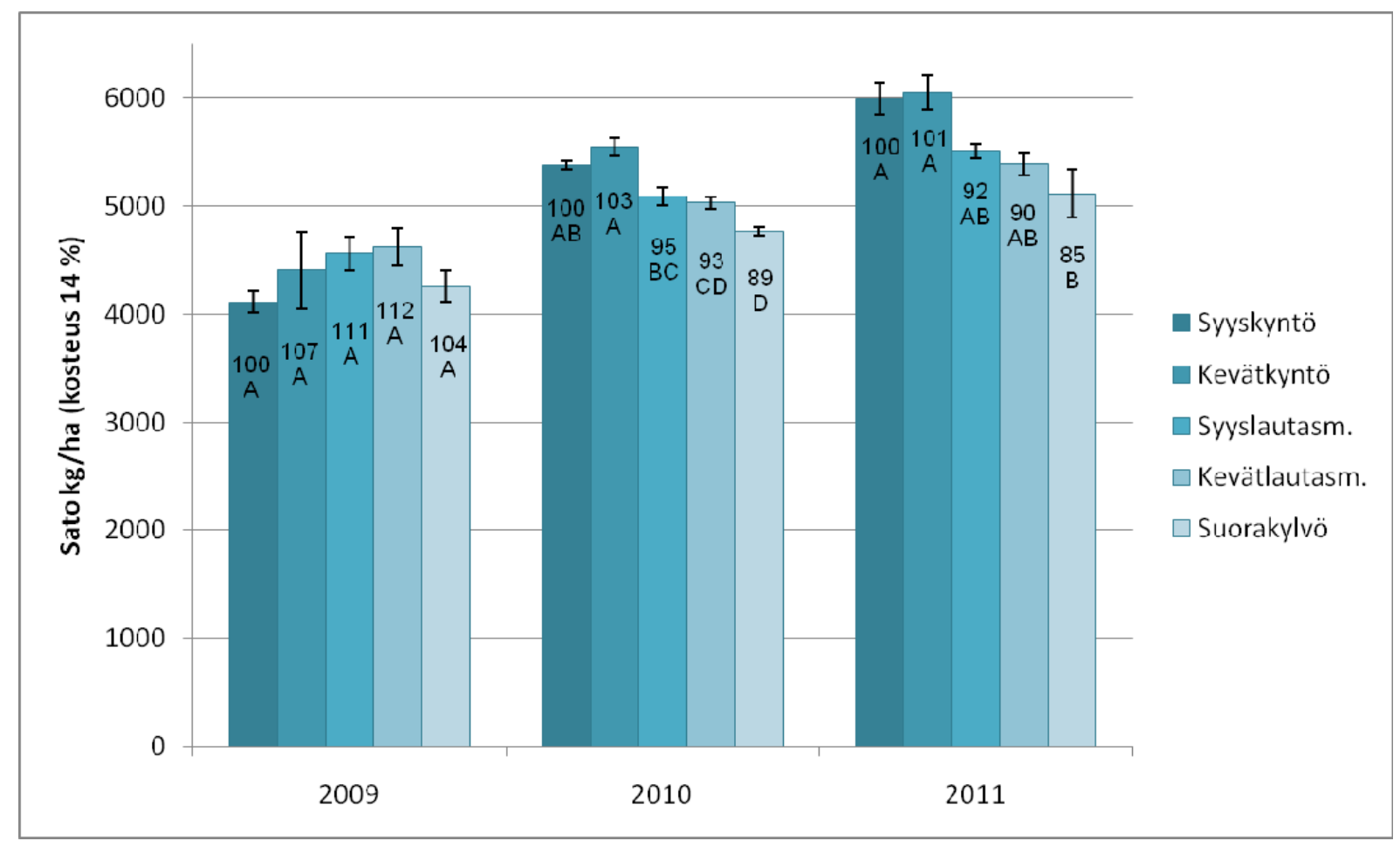

Kuva 1. Ohrasadot turvemaan kokeelta vuosilta 2009 - 2011 (Ruukki). Neljän kerranteen keskihajonta on merkitty janalla ja Syyskynnön sadolle on annettu vuosittain suhdeluvuksi 100. Koejäsenten välinen ero on tilastollisesti merkitsevä, jollei niitä ole merkitty yhteisellä kirjaimella. Koejäsenten välisiä suhdelukuja ja merkitsevyyksiä voi verrata vain koevuosien sisällä, ei koevuosien välillä.

Turvemaalla suorakylvö toimi hyvin, keskimäärin saatiin noin $10 \%$ alempi sato kuin syyskynnöllä. Ero oli tilastollisesti merkitsevä lukuunottamatta vuotta 2009, jolloin voimakas lakoontuminen haittasi puintia. Kummallakin hietamaan koepaikalla suorakylvettyjen ruutujen sato oli kahtena ensimmäisenä vuonna vähintään 30 \% alempi kuin syyskynnettyjen ruutujen. Haapajärvellä suorakylvö epäonnistui täysin ensimmäisenä vuonna (kuvat 2 ja 3). Syitä oli useita: alueilla esiintyi runsaasti kylänurmikkaa, johon torjunta-aineet eivät tehonneet, yhtenä keväänä maa oli liian kostea suorakylvön kannalta ja Kannuksen koepaikalla vannaspaine oli liian alhainen suhteessa maan kovuuteen, jolloin siemenet jäivät liian pintaan ja itivät epätasaisesti. Kasvukaudella 2011 suorakylvö onnistui hietamaillakin aiempia vuosia paremmin ja sato ei ollut enää merkitsevästi huonompi kyntöön verrattuna. Kylänurmikkaa taimettui aiempia vuosia vähemmän ja Kannuksen kokeella vannaspaineet saatiin säädettyä riittävän suuriksi.

Kultivointi syksyllä ilman mitään kevätmuokkausta tuotti 30 - 50 \% syyskyntöä heikomman sadon, mutta kannattaa muistaa, että kultivointi oli mukana vain yhdellä koepaikalla (kuva 2). Tällä koepaikalla kultivointi oli vielä hieman heikompi kuin syksyllä tehty lautasmuokkaus, vaikkakaan ero ei ollut tilastollisesti merkitsevä. Kylänurmikka ehti taimettua kumpaankin syksyllä tehtyyn kevytmuokkaukseen jo ennen kylvöä. Lisäksi kultivoinnin jälkeen maa jäi epätasaisemmaksi kuin lautasmuokkauksen jälkeen, joten kylvö ja ohran orastuminen kultivoidussa maassa oli epätasaista. Kumpikin syksyllä tehdyistä kevytmuokkauksista olisi todennäköisesti hyötynyt merkittävästi vielä ennen kylvöä tehdystä muokkauksesta.

Ohrasadon hehtolitrapainot eivät eronneet merkitsevästi millään koepaikalla toisistaan minään koevuonna. Joinakin vuosina jäätiin kauppakelpoisuusrajan alle kuivuudesta tai lakoutumisesta johtuen, mutta koejäsenten välillä ei ollut eroa. Puintikosteutta ei mitattu joka vuonna, mutta Ruukissa se oli kahtena syksynä suorakylvössä noin 4 \%-yksikköä korkeampi verrattuna kyntöön. Kevytmuokatuissa koejäsenissä kosteus oli noina vuosina noin 2 \%-yksikköä kyntöä korkeampi. Ts. puintiaikaan viljan valmistuminen lienee ollut vielä hieman kesken suorakylvössä ja kevytmuokkauksissa, vaikka kaikissa tapauksissa viljan kylvöstä oli kulunut vähintään 90 vrk. 


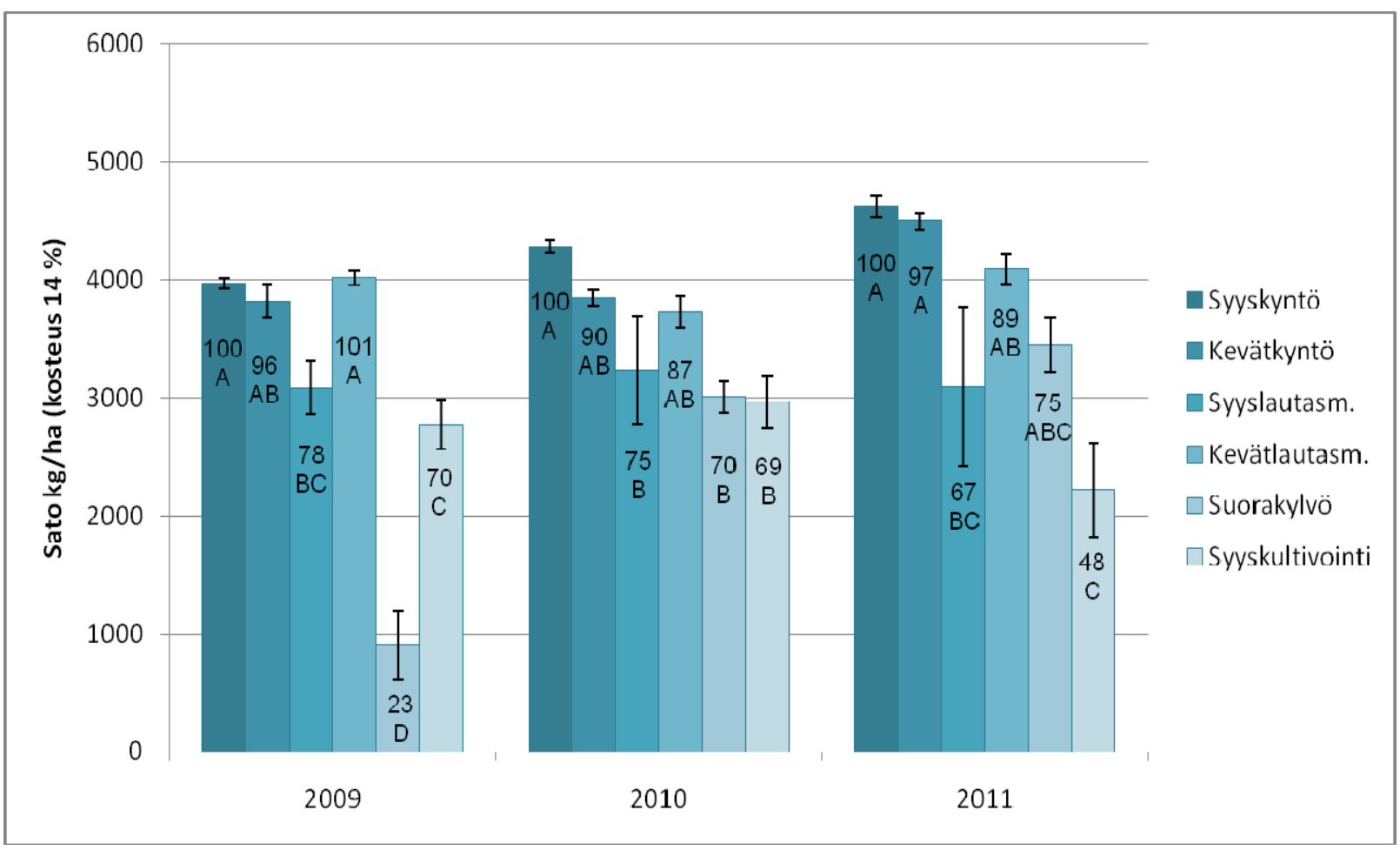

Kuva 2. Ohrasadot hietamaan kokeelta vuosilta 2009 - 2011 (Haapajärvi). Neljän kerranteen keskihajonta on merkitty janalla ja Syyskynnön sadolle on annettu vuosittain suhdeluvuksi 100. Koejäsenten välinen ero on tilastollisesti merkitsevä, jollei niitä ole merkitty yhteisellä kirjaimella. Koejäsenten välisiä suhdelukuja ja merkitsevyyksiä voi verrata vain koevuosien sisällä, ei koevuosien välillä.

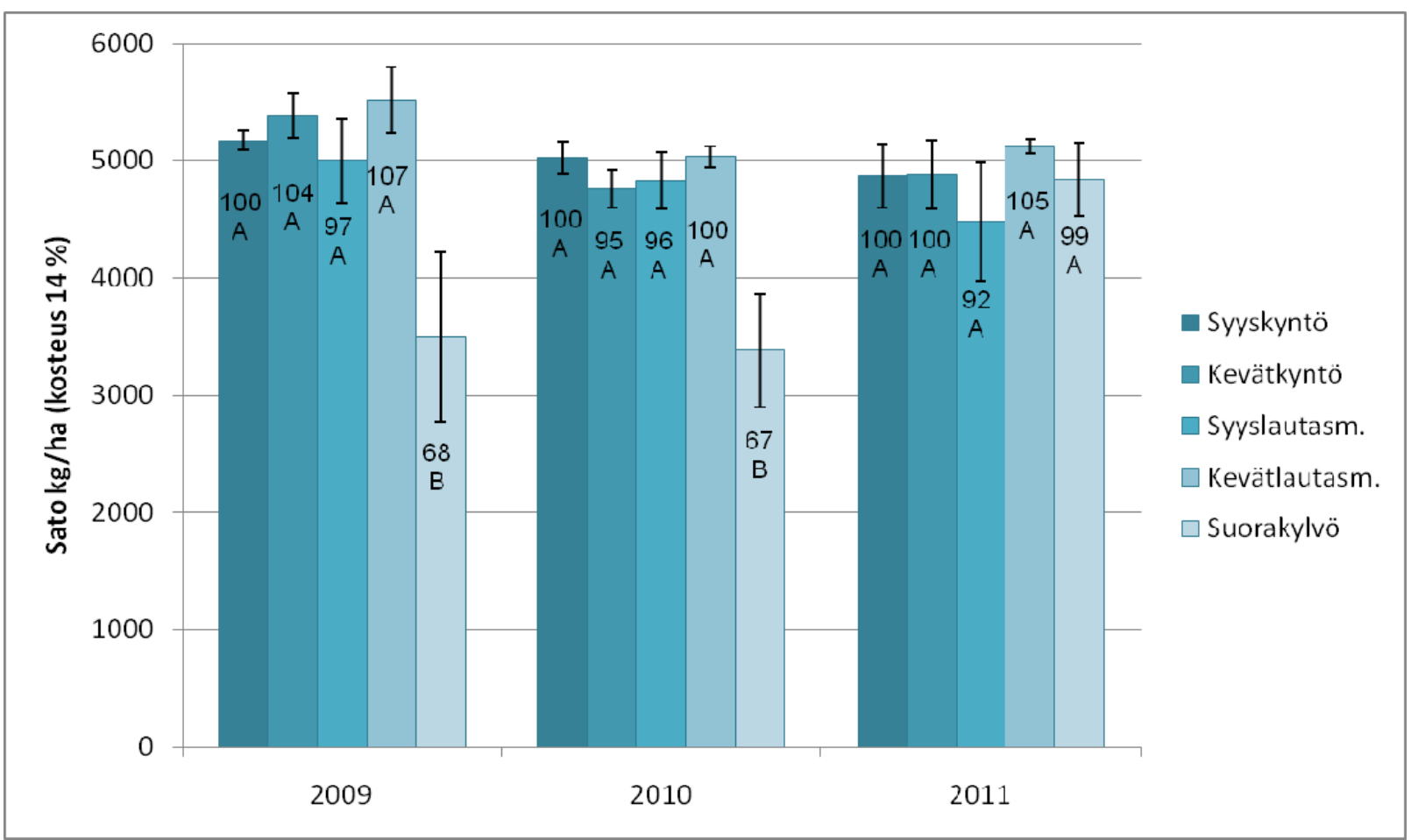

Kuva 3. Ohrasadot hietamaan kokeelta vuosilta 2009 - 2011 (Kannus). Neljän kerranteen keskihajonta on merkitty janalla ja Syyskynnön sadolle on annettu vuosittain suhdeluvuksi 100. Koejäsenten välinen ero on tilastollisesti merkitsevä, jollei niitä ole merkitty yhteisellä kirjaimella. Koejäsenten välisiä suhdelukuja ja merkitsevyyksiä voi verrata vain koevuosien sisällä, ei koevuosien välillä. 
Kasvitauteja arvioitiin koeruuduilta silmämääräisesti, mutta selviä eroja ei koejäsenten välillä ollut, vaikka oljet silputtiin vuosittain peltoon. Osaltaan tätä selittävät suhteellisen kuivat kasvukaudet tutkimuksen aikana.

Kustannuslaskelmien mukaan kyntöön pohjautuvalla ketjulla kasvuston perustaminen maksaa noin 190 e/ha ja suorakylvöllä noin 100 e/ha, kun glyfosaattiruiskutus otetaan laskelmaan mukaan (kuva 4). Kevytmuokkausketjuilla perustamiskustannus on näiden kahden ääripään välillä. Vaikka esimerkiksi lautasmuokkaimella ajettaisiin kahteen kertaan, jäisi se vielä noin 45 e/ha kyntöä edullisemmaksi. Jos tähän vielä lisätään yksi äestys S-piikkiäkeellä, kustannukset nousevat jo hyvin lähelle kynnön kustannuksia.

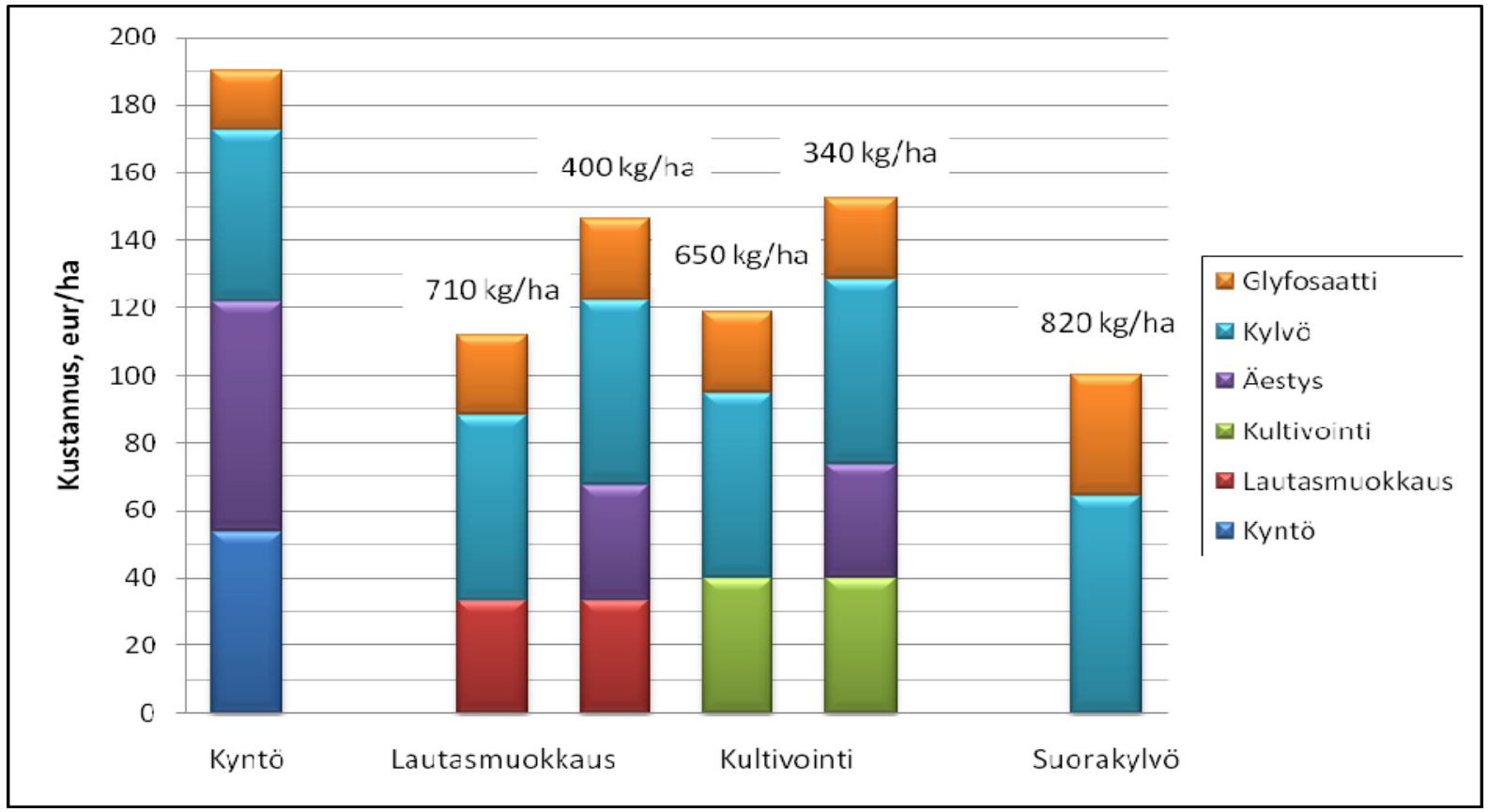

Kuva 4. Viljakasvuston perustamiskustannus eri muokkaus- ja kylvömenetelmillä. Laskennassa on käytetty TTS:n keräämiä urakointihintatilastoja (Palva 2011). Pylväiden yläpuolella olevat luvut ilmaisevat, kuinka paljon ohrasato saa enintään olla alempi verrattuna kyntämällä saatavaan satoon, jotta menetelmän käyttö olisi kannattavaa. Ohran myyntihintana on käytetty 150 e/tonni. Kevytmuokkauksille on laskettu kustannukset ilman kylvöä edeltävää äestystä ja äestyksen kanssa. Hinnat v. 2011, alv. 0 \%.

Kun viljan myyntihinta on 150 e/tonni (pystyhinta pellolla 110 e/tonni), niin suorakylvöllä saatava sato saa olla enintään $820 \mathrm{~kg} /$ ha alempi kuin kyntämällä saatu sato, jotta suorakylvön tuomalla kustannussäästöllä olisi merkitystä (kuva 4). Satotason ollessa $5000 \mathrm{~kg} / \mathrm{ha}$ tämä on noin $16 \%$. Kevytmuokkauksilla sadon alenema saisi olla enintään 340 - $710 \mathrm{~kg} / \mathrm{ha}$. Viljan myyntihinnan ollessa 200 e/tonni suorakylvö saisi laskea satoa enintään $560 \mathrm{~kg} / \mathrm{ha}$ ja viljan hinnan ollessa 100 e/tonni sadon alenema saisi olla enintään $1500 \mathrm{~kg} / \mathrm{ha}$.

Tässä laskelmassa ei ole otettu huomioon kevytmuokkauksesta tai suorakylvöstä mahdollisesti saatavaa lisätukea, koska se vaihtelee tukialueen ja tilan rakenteen mukaan. Myöskään ei ole huomioitu kuivauskustannusten mahdollista lisääntymistä muokkausta kevennettäessä. Nämä kaksi asiaa vaikuttavat tarkastelussa eri suuntiin, joten virhe lopputuloksessa ei liene kovin suuri.

\section{Johtopäätökset}

Muokkausmenetelmät vaikuttivat ohran satoihin tässä tutkimuksessa ennalta arveltua enemmän. Kynnöllä tai keväällä tehdyllä kevytmuokkauksella saatiin tasaisen hyviä satoja, muissa menetelmissä satovaihtelu oli suurempaa. Sadon laatuun ei ollut vaikutuksia. Aiemmassa suorakylvöä ja kyntöä keveillä mailla vertailleessa tutkimuksessa (Isolahti ym. 2008) satoerot jäivät pienemmiksi. Toisaalta Etelä-Suomen savimailla tehdyssä suorakylvötutkimuksessa (Känkänen ym. 2011), havaittiin suurta vuosittaista satovaihtelua suorakylvön ja syyskynnön ohrasatojen välillä. Suorakylvön sato oli erityi- 
sen heikko märkinä kesinä. Korostettakoon, että jokainen näistä kolmesta tutkimuksesta on kestänyt vain kolme kasvukautta, eli on nähty vasta siirtymäkautta kynnöstä aurattomaan viljelyyn.

Nyt käsillä olevan tutkimukseen ei sattunut yhtään erityisen märkää kasvukautta, kesät olivat pikemminkin tavanomaista lämpimämpiä ja kuivempia. Lisäksi ojitus oli kaikilla koepaikoilla kohtuullisen hyvässä kunnossa. Märkyys ei siis selitä satoeroja, vaikkakin Haapajärven koepaikalla 2009 suorakylvö tehtiinkin liian kosteaan maahan.

Ruukin turvemaalla satoerot muokkausmenetelmien välillä olivat pienimmät (max. 15 \%). Siellä pääasiallinen rikkakasvi oli juolavehnä, johon glyfosaattiruiskutukset tehosivat hyvin. Sen sijaan Haapajärvellä ja Kannuksessa ongelmia oli valvatista ja etenkin kylänurmikasta. Valvatti saatiin hyvin kuriin viljan orasvaiheen ruiskutuksia tehostamalla, mutta kylänurmikkaa ei saatu tällä tavoin torjutuksi. Syksyllä tehdyn glyfosaattiruiskutuksen aikaan tämä heinämäinen kertarikkakasvi oli jo varistanut siemenensä. Vaikka kylänurmikka ei kasva kovin korkeaksi, se muodostaa alkukasvukaudesta tiheitä nurmimattoja, joissa viljelykasvien oraiden kilpailu on vaikeaa.

Kylänurmikan taimet eivät kestä kovin hyvin muokkausta ja siten nurmikasta ei ollut mitään haittaa kynnetyissä ja ennen kylvöä äestetyissä tai keväillä lautasmuokatuissa koeruuduissa. Sen sijaan selvää haittaa oli vain syksyllä kevytmuokatuissa ruuduissa, joissa nurmikka iti jo syksyllä tai aikaisin keväällä. Suorakylvökoneen vantaisto ei näitä taimia tuhonnut. Näissä käsittelyissä nurmikka olisi melko varmasti saatu kuriin kylvöä edeltävällä äestyksellä ja ohrasato olisi siten parantunut huomattavasti. Viimeisenä koevuotena oli keväällä selvästi havaittavissa, että nurmikkaa ei taimettunut suorakylvössä enää niin paljon kuin aiemmin. Koska maata käännetään menetelmässä vain vähän, uusia nurmikan siemeniä ei enää orastunut kovin paljoa.

Kevät- ja syyskynnön välinen satoero oli tässä tutkimuksessa melko vähäinen, kuten se oli aiemmassakin suorakylvötutkimuksessa (Isolahti ym. 2008). Turve- ja hietamailla kynnön voi siis tehdä yhtä hyvin syksyllä tai keväällä, ellei paikka ole äärimmäisen poudanarka. Kevätkynnössä kylvö kannattaa tehdä suhteellisen pian kynnön jälkeen, ettei kevätkosteutta menetetä liikaa.

Syksyllä tehdyn lautasmuokkauksen ja kultivoinnin heikompaa menestystä verrattuna keväällä tehtyyn lautasmuokkaukseen selittänee maan nopeampi lämpiäminen muokkauksen jälkeen edellä kuvatun kylänurmikkaongelman lisäksi. Syksyllä runsas kasvijätteiden määrä johti myös epätasaiseen muokkausjälkeen, johon tehty kylvö ei orastunut yhtä tasaisesti kuin keväällä tehdyn lautasmuokkauksen jälkeen. Tältäkin kannalta syysmuokatut kevyet maat kannattaisi muokata vielä uudelleen ennen kylvöä. Savimailla tilanne voi olla toinen.

Kannattavuuslaskelman mukaan Ruukissa lautasmuokkaus ja suorakylvö näyttivät kannattavilta kyntöön verrattuna, joskaan ero ei ollut suuri. Kannuksessa lautasmuokkaukset pärjäsivät kynnölle, mutta suorakylvö ainoastaan viimeisenä vuonna. Haapajärvellä, missä rikkakasvipaine oli kova, kynnölle pärjäsi ainoastaan keväällä tehty lautasmuokkaus.

Näillä maalajeilla sopiva viljakasvuston perustamistapa voisi olla keväällä tehty kevytmuokkaus yhdistettynä robustiin kiekkovannaskylvökoneeseen. Jos halutaan kevytmuokata jo syksyllä, kannattaisi keväälläkin ajaa vielä kertaalleen kevytmuokkarilla tai äkeellä ennen kylvöä. Toisaalta kyntökin on edelleen hyvä vaihtoehto, koska se ei kevyillä mailla kuluta kovin runsaasti energiaa, sillä voidaan säästää kestorikkakasvi- sekä tautiruiskutuksissa ja kyntäen satovaihtelut olivat tässä tutkimuksessa pienimpiä. Kyntäen pellon pintakerros tulee myös ilmavaksi, jolloin siihen mahtuu sateisina kesinä enemmän vettä, eivätkä kasvit huku niin helposti kuin pinnallisemmissa muokkaustavoissa.

Kiitokset hanketta rahoittaneille Pohjois-Pohjanmaan Ely-keskukselle, Pohjanmaan Ely-keskukselle, Vieskan Metalli Oy:lle ja Agrimarket Oy:lle. Lisäksi kiitokset Haapajärven ja Kannuksen koulutilojen sekä MTT Ruukin henkilökunnalle hyvin sujuneesta yhteistyöstä.

\section{Kirjallisuus:}

Isolahti, M., Lötjönen, T. \& Uusitalo, R. 2008. Suorakylvön soveltuvuus nautakarjatilojen viljanviljelyyn. Maa- ja elintarviketalous 118. Jokioinen, Finland: MTT. 56 s. http://www.mtt.fi/met/pdf/met118.pdf

Känkänen, H., Alakukku, L., Salo, Y. \& Pitkänen, T. 2011. Growth and yield of spring cereals during transition to zero tillage on clay soils. European journal of agronomy 34, 1: 35-45.

Palva, R. 2011. Konetyön kustannukset ja tilastolliset urakointihinnat. TTS:n tiedote: Maataloustyö ja tuottavuus 4/2011 (631). Vaasa: Työtehoseura. 12 s.

Pitkänen, J. \& Mikkola, H. 1998. Muokkausopas. Käytännön Maamiehen liite 3/98. 32 s. 